\author{
Mario Slugan \\ Queen Mary University of London, Mile End Rd, Bethnal Green, London E1 4NS UK \\ m.slugan@qmul.ac.uk
}

\title{
Fikcijske emocije i moralna dimenzija paradoksa fikcije u filmu
}

\begin{abstract}
Sažetak
Nudi se dvojaka intervencija u debatu o paradoksu fikcije temeljenu na introspekciji i analitičkoj argumentaciji. Prvo, argumentira se da su se dosadašnje rasprave o paradoksu previše fokusirale na njegovu epistemološku dimenziju. To je dovelo da zanemarivanja moralne strane paradoksa, tj. malo je rečeno o tome da redovito više marimo za fikcijske entitete, nego što marimo za stvarne ljude. Drugo, predlaže se da su redovito, iako ne isključivo, strukture stvarnog života, a ne fikcijski entiteti, te koje uzrokuju emocije. U hororima, primjerice, ne bojimo se fikcijskog čudovišta, nego mogućnosti, ma koliko ona bila nevjerojatna, da nešto poput toga postoji u stvarnom svijetu. Bitno je primijetiti da se ovaj prijedlog razlikuje od pristupa temeljenih na protučinjenicama (counterfactualism) zato što dozvoljava da uzrok nekih emocija budu fikcijski entiteti. To su emocije poput simpatije $i$ antipatije koje nemaju jasno definirane povezane tipične akcije.
\end{abstract}

\section{Ključne riječi}

paradoks fikcije, emocije, moral, film

U svojoj originalnoj inačici, paradoks fikcije uključuje tri propozicije (Radford i Weston 1975; Walton 1978). Zasebno, one se intuitivno doimaju ispravnima, no zajedno ne mogu sve biti istinite istovremeno: (1) fikcijski entiteti (likovi, objekti, događaji itd.) uzrokuju autentične emocije; (2) samo entiteti za koje vjerujemo da uistinu postoje mogu uzrokovati autentične emocije; (3) ne vjerujemo da fikcijski entiteti uistinu postoje. ${ }^{1}$ Trenutno je dominantan stav da paradoks fikcije uopće nije paradoks, tj. većina istraživača drži da je (2) pogrešan (Stecker 2011; Friend 2017; Konrad, Petraschka i Werner 2018; Kroon i Voltolini 2019). Drugim riječima, po rješenju s najviše pobornika postoje brojni objekti i događaji za koje ne vjerujemo da postoje, a ipak uzrokuju autentične emocije (Carroll 1990). Primjerice, seksualne fantazije redovito vode stvarnim emocionalnim reakcijama. U slučaju horora, po toj teoriji, uistinu se bojimo fikcijskog čudovišta koje vreba u sjenkama.

Postoje, dakako, i druga rješenja. Neki poriču (3). Samuel Taylor Coleridge (1817) predložio je da čitatelji voljno suspendiraju nevjericu u svom angažmanu s fikcijskim entitetima. Nama nešto bliže, David B. Suits (2006) argumentirao je da zato što je moguće istovremeno vjerovati $p$ i ne- $p$ također je moguće istovremeno vjerovati i ne vjerovati u fikcijske entitete. Drugi odbacuju (2). Najpoznatiji među njima, Kendall Walton $(1978,1990)$, tvrdi da fikcijski entiteti uzrokuju samo kvazi-emocije koje trebamo razlikovati od emocija u kontekstu stvarnog života. Sročeno nešto drugačije, po Waltonovu mišljenju, kon-

Ovdje ću razlikovati fikciju (termin kojim označujem fikcijska umjetnička djela) od fikcijskog entiteta. U tom smislu, fikcija je stvarni materijalni objekt dio čijeg sadržaja čine fikcijski entiteti. 
zumenti fikcija samo zamišljaju da osjećaju emocije spram fikcijskih entiteta. Neovisno o predloženom rješenju za veliku većinu onih uključenih u debatu, ključan je stav taj da u našem angažmanu s fikcijom fikcijski entiteti (neovisno o tome vjerujemo li u njih ili ne) uzrokuju emocije ovoga ili onoga tipa. No što ako uzrok tih emocija nisu fikcijski entiteti ili što ako u najmanju ruku fikcijski entiteti uzrokuju emocije u mnogo manje slučaja nego li se prethodno mislilo? I što ako nam fokus na epistemološki aspekt problema onemogućava da prepoznamo ozbiljniju dimenziju problema - onu moralnu?

\section{Moralna dimenzija paradoksa fikcije}

Neporecivo je da se moralna pitanja razmatraju u diskusijama problema i paradoksa imaginacije u umjetnosti. Problem imaginativnog otpora često se vrti oko teškoće zamišljanja »moralno devijantnih« fikcijskih svjetova, poput svijeta u kojemu je ubiti ljude koji su krivi za gužvu u prometu moralno ispravno (Hume 1857, Weatherson 2004: 1). Još od Platona mnogo je toga rečeno o ulozi imaginacije i umjetnosti u moralnom uvjeravanju (za pregled vidi Eaton 2015; Liao i Gendler 2019). Postoji i literatura o tome zašto simpatiziramo moralno odvratne likove poput Tonyja Soprana (gl. James Gandolfini) iz Obitelji Soprano (HBO, 1999. - 2007.), iako bi nam se u stvarnom životu gadili (Smith 2011; Vaage 2015; Slugan 2019). No kada se radi o paradoksu fikcije, autori identificiraju samo njegovu deskriptivnu i normativnu dimenziju (usp. Friend 2017). Dok deskriptivno pitanje pita o tome jesu li emocije koje uzrokuju fikcijski entiteti iste kao i one koje uzrokuju strukture stvarnog života, normativno se pitanje tiče toga jesu li emocije koje uzrokuju fikcijski entiteti nekako neprikladne.

Važno je primijetiti to da ni deskriptivno, ni normativno pitanje nema moralnu dimenziju. Deskriptivno se pitanje bavi samo kategorizacijom. No čak i normativno pitanje shvaća (ne)prikladnost u terminima subjektivne racionalnosti ili opravdanja (Radford i Weston 1975), a ne moralnosti. U ovom kontekstu emocija je opravdana ako je prikladna u odnosu na dokaze o situaciji. Ako imam dobar razlog vjerovati da me prijatelj iznevjerio, moj je gnjev opravdan. No kada bi se pokazalo da me prijatelj zapravo nije iznevjerio, ne bih više bio opravdan ljutiti se na njega. Isto tako, ako mi kolega ispriča tragičnu priču o svojoj sestri i tako izmami moje sažaljenje, ali tada otkrije da zapravo nema sestru, moja sućut spram nje postaje neopravdanom jer njegova sestra zapravo ne postoji. Po Radfordovu i Westonovu mišljenju, emocije uzrokovane fikcijskim entitetima su upravo ovog tipa - neopravdane - zbog toga što nemaju prikladan objekt.

Ovaj članak predlaže da postoji moralna dimenzija paradoksa koja do danas nije dobila značajniju pozornost. Govorim o fenomenu gdje se čini da gledatelji i čitatelji više mare o fikcijskim entitetima nego li o ljudima i događajima iz stvarnog života. Kratka pretraga na internetu otkriva niz diskusija na forumima poput Quore i Reddita, gdje korisnici postavljaju i odgovaraju na pitanja kao što su »zašto preferiram fikcijske likove spram stvarnih ljudi?«, "zašto nemam empatiju za stvarne ljude, nego samo za fikcijske likove?« i »osjeća li itko empatiju za fikcijske likove, ali praktički ništa za stvarne ljude? «. ${ }^{2}$ Prijetnje glumici Anni Gunn zbog njena utjelovljenja Skyler White u Na putu prema dolje (AMC, 2008. - 2013.) ili tinejdžerska zaluđenost vampirskim protagonistom Sumrak sage (2008. - 2012.) Edwardom Cullenom također su primjer ove pojave. 
Da bismo bolje shvatili kako duboke ove emocije mogu biti, ponudit ću vlastiti slučaj gledanja Igre prijestolja (HBO, 2011. - 2019.) kao anegdotalni dokaz. U osmoj epizodi četvrte sezone - »Planina i Otrovnica« - Tyrion Lannister (gl. Peter Dinklage) čeka ishod suđenja borbom nakon što se Oberyn Martell, znan kao Otrovnica (gl. Pedro Pascal), ponudio da ga zastupa protiv Lorda Gregora, titularne Planine (gl. Hafpór Júlíus Björnsson). Oberyn dominira čitavom borbom no jednom kada baci Gregora na tlo, umjesto da ga dokrajči on zahtijeva priznanje zločina iz prošlosti. Gregor iskoristi ovu priliku da se dočepa Oberyna i smrska mu lubanju golim rukama. Time je Tyrion osuđen na smrt i epizoda završi.

Sjećam se da me ovo toliko uznemirilo da se nisam mogao pomiriti s tim što se dogodilo čitav tjedan (sve do sljedeće epizode kada je priča otišla u drugom smjeru). I sjećam se da sam pokušavao shvatiti zašto sam toliko pogođen jer se nisam mogao prisjetiti kada me zadnji puta nešto toliko izbacilo iz takta. Najvažnije je to što je to 'nešto' uključivalo i događaje iz stvarnog života. Čak ni izvještaji o ratnim zločinima Islamske države za vrijeme izvornog emitiranja epizode - ljeta 2014. - nisu se približili takvom emocionalnom intenzitetu. U ovom kontekstu problem prvenstveno mora biti moralne, a ne epistemološke prirode - kako to da me fikcijski događaj može toliko uznemiriti kada u usporedbi s time marim toliko malo u slučaju faktičkih suvremenih zvjerstava?

Primjer je anegdotalan i možda bi se mogao odbaciti jednostavno kao simptom antisocijalnog poremećaja osobnosti. Nasuprot tome, argumentirat ću da su dublje emocionalne reakcije na patnje fikcijskih likova nego na patnje osoba $\mathrm{u}$ stvarnom životu uobičajena pojava. Uzmite u obzir patnju Vašeg omiljenog fikcijskog lika i usporedite intenzitet tog osjećaja s time što osjećate kada, recimo, sretnete beskućnika na cesti. Ili se samo sjetite koliko ste puta zaplakali nakon što ste pročitali crnu kroniku u usporedbi s time koliko ste često 'pustili suzu' tijekom gledanja Vaše omiljene melodrame. Da ste i samo jednom zaplakali nad sudbinom fikcijskih likova, kao što je to smrt Leejeve (Casey Affleck) djece u požaru zbog njegova nemara u Manchesteru pokraj mora (Kenneth Lonergan, 2015.), a da pritom nijednom niste zaplakali nakon izvještaja o stvarnim tragedijama izbjeglica koji se utapaju u Mediteranu ili pogibaju u Siriji, dovoljno je da osvijesti moralnu dimenziju paradoksa fikcije. Formalno sročeno:

$\mathrm{x})$ većina konzumenata fikcije makar je jednom imala intenzivan emocionalan odgovor na fikcijski entitet (mržnja, zaluđenost, plakanje itd.);

y) većina konzumenata fikcije barem jednom nije imala intenzivnu emocionalnu reakciju na stvarnu tragediju;

Usp. John Edwards, »Why do I have no empathy for real people, only fictional characters?«, Quora (24. 12. 2016.). Dostupno na: https://www.quora.com/Whydo-I-have-no-empathy-for-real-peopleonly-fictional-characters\#: : text $=\mathrm{It} \% 20$ may $\% 20$ be $\% 20 \mathrm{a} \% 20$ defense, you $\% 20$ to $\% 20$ behave\%20this\%20way. (pristupljeno 3. 2. 2020.). Edward Feder, »I can only feel empathy, sympathy, and love towards fictional characters. I have none towards real people, including my family. What is wrong with me?«, Quora (12. 12. 2019.). Dostupno na:
https://www.quora.com/I-can-only-feelempathy-sympathy-and-love-towardsfictional-characters-I-have-none-towardsreal-people-including-my-family-What-iswrong-with-me (pristupljeno 3. 2. 2020.). Christopher Simpson, »Why do I feel little to no empathy for real people but I'm able to feel it for the characters in a movie, TV series, etc?«, Quora (28. 6. 2019.). Dostupno na: https://www.quora.com/Why-do-I-feel-littleto-no-empathy-for-real-people-but-Im-ableto-feel-it-for-the-characters-in-a-movie-TVseries-etc (pristupljeno 3. 2. 2020.). 
z) iz (x) i (y) slijedi da je uobičajena pojava mariti dublje (imati intenzivnije emocije) za neke entitete iz fikcije nego li za mnoge iz stvarnog života.

Ovakvi primjeri i ovaj argument također bi trebali biti dovoljni da eliminiraju kritike koje prizivaju patologije poput antisocijalnog poremećaja osobnosti u mom anegdotalnom slučaju ili, suprotno, demonstriraju da svi koji doživljavaju fikciju na uobičajeni način pate od tog poremećaja.

Problem koji možemo nazvati moralnim problemom fikcije (MPF) može se formalizirati na sljedeći način:

(A) Trebamo dublje mariti za entitete iz stvarnog života nego li za one iz fikcije.

(B) Uobičajena je pojava mariti dublje (imati intenzivnije emocije) za neke entitete iz fikcije nego li za mnoge iz stvarnog života.

MPF baca drugačije svjetlo na paradoks fikcije od njegove normativne dimenzije. MPF nije o opravdavanju emocija, nego o usporedbama s emocijama u kontekstu stvarnog života. Dok se u raspravama normativnosti emocionalna reakcija čini iracionalnom, u MPF-u intenzitet emocije veći je od onoga što bi bilo primjereno za emocionalni odgovor na entitet iz stvarnog života. U MPF-u ne radi se o tome da je emocionalna reakcija neprikladna u Radfordovu i Westonovu smislu, nego o skandalu da emocionalni odgovor na fikcijski entitet uopće postoji dok isti ili potpuno izostaje ili je manjeg intenziteta $\mathrm{u}$ kontekstu stvarnog života. Drugim riječima, u nastojanju da riješimo ovaj problem neće nam pomoći argumentirati protiv Radforda i Westona tako što ćemo identificirati načine na koje emocionalne reakcije na fikcijske entitete ipak mogu biti racionalne ili kako drugačije norme opravdavanja vrijede za fikcijske emocije naspram onima iz konteksta stvarnog života (za preglede vidi Friend 2017; Liao i Gendler 2019). Naspram toga, predlažem de rješenje potražimo u poricanju (B). Ideju ću prvo skicirati na primjeru Igre prijestolja. Kada sam pokušavao shvatiti intenzitet svoje reakcije na završetak gore opisane borbe, bilo mi je jasno da objekt mojih emocija nije bio Oberyn. Ono što me toliko pogodilo bila je posljedica Oberynove smrt - to što je ona potpisala Tyrionovu smrtnu kaznu. No tada sam se počeo pitati je li uistinu Tyrion onaj za kojega se bojim ili me zapravo brine nešto drugo. Tyrion je očigledno bio moj omiljeni lik u seriji i s njim van slike jasno je da više ne bih ni približno uživao u programu. Njegove šale i cinične doskočice poput »Svi patuljci su kopilad u očima njihovih otaca.« bili su stalni izvor užitka i zabave. Iz ove perspektive, ono što je uistinu imalo emocionalni efekt na mene bila je mogućnost da više neću toliko uživati u seriji - to što više neće biti strukture koja će omogućavati izvedbu ovakvih pošalica - a ne bojazan za život nekog fikcijskog lika. U istom ključu, pošto sam već bio uložio značajnu količinu vremena u seriju, imam interes u tome da mi se taj ulog vraća u obliku ovakvog tipa užitka. Činjenica da sam reartikulirao svoje emocionalne reakcije na ovaj način - kao ulog vremena i očekivanje određenog oblika zabave razoružava MPF.

Glavna je ideja ovoga članka, dakle, da je moguće primijeniti opisanu liniju obrazloženja na paradoks fikcije. Drugim riječima, moguće je zaobići klasično rješenje paradoksa fikcije - poricanje (2) - tako da ono na što se emocije odnose nisu fikcijski entiteti, nego strukture stvarnog života, uključujući vremenski ulog i narativna očekivanja. Štoviše, jednom kada prepoznamo postojanje MPF-a, imamo novi i vjerojatno bitniji poticaj na to da riješimo 
paradoks fikcije koji je s one strane epistemoloških briga. Istovremeno, ovo nije replikacija rješenja koja se temelje na protučinjenicama (Weston 1975; Paskins 1977; Charlton 1984, 1986; McCormick 1988; usp. Yanal 1999). Drugačije govoreći, tvrdim da se klasični primjeri u ovim diskusijama mogu reartikulirati na taj način da se odnose na različite strukture iz stvarnog života. Sročeno još drugačije, ovdje se radi više o argumentiranju da se paradoks fikcije često može zaobići, nego o tome što je rješenje paradoksa.

Metodološki, pristup je dvojak. S jedne strane, na temelju introspekcijske analize predlažem da su objekti različitih emocija redovito strukture stvarnog života, a ne fikcijski entiteti. U najmanju ruku predlažem da objekte različitih emocija možemo opisati kao strukture stvarnog života, pri čemu, hoćemo li prihvatiti taj opis u prvom redu ovisi o tome koliko blisko on odgovara našem fenomenološkom iskustvu emocionalne interakcije s fikcijskim djelima. S druge strane, iz teoretske perspektive, opis objekata emocija u terminima struktura stvarnog života razoružava MPF te, u slučaju horora, objašnjava neke njegove bitne žanrovske odrednice.

\section{Bez straha (od fikcijskih entiteta)}

Waltonovo sluzavo čudovište i Charles, gledatelj koji ga se boji, očigledno je prvi slučaj na kojemu treba isprobati gornju ideju. ${ }^{3} \mathrm{U}$ Waltonovu slavnom primjeru, kada se Charles, surogat za standardnog gledatelja, gledajući horor film suoči sa sluzavim monstrumom na ekranu, on ga se boji:

»Njegovi su mišići napeti, hvata se za kosu, njegov puls je ubrzan, njegov adrenalin teče. Nazovimo ovo fiziološko/psihološko stanje 'kvazi-strah'.« (Walton 1978: 6)

To što Walton govori o kvazi-emocijama i, kao što je objašnjeno gore, poriče (1) umjesto (2), ne bi nas trebalo brinuti jer je poanta zaobići paradoks, a ne ispitivati njegova standardna rješenja. Drugim riječima, tvrdim da se Charles ne boji sluzavog čudovišta (ni autentično ni kvazi) kao fikcijskog entiteta, nego da se boji struktura stvarnog života. Zanimljivo, Walton se nakratko bavi potonjom mogućnošću:

»Ako je Charles dijete, film ga može ponukati da se zapita ne postoji li možda stvarna sluzava čudovišta ili drugi egzotični monstrumi poput onih prikazanih u filmu, čak i ako u potpunosti shvaća da filmsko čudovište samo nije stvarno. Charles se možda i boji ovih potencijalnih stvarnih opasnosti; možda će imati noćne more danima (Ralje su dovele do toga da se mnogo ljudi boje morskih pasa za koje su mislili da možda stvarno postoje. Ali da li su se bojali fikcijskih morskih pasa u filmu je drugo pitanje.).« (Walton 1978: 10)

Ovo je Waltonova prva i jedina referenca na ovakvo rješenje i on ga eliminira odmah jednako brzo kao što ga uvodi. Walton tvrdi da je pitanje o tome boje li se gledatelji fikcijskih morskih pasa različito od pitanja o tome boje li se struktura stvarnog života (potencijalno ili stvarno postojećih čudovišta). No to je točno samo ako smo se već unaprijed složili da se strah od fikcijskih entiteta ne svodi na strah od struktura stvarnog života. Striktno govoreći, Walton samo pretpostavlja da prvi nije moguće svesti na drugi. Naspram toga, iz perspektive fenomenološkog opisa objekta emocija pokušat ću pokazati da Walton nije $u$ pravu kada ovakvo objašnjenje odbacuje kao rubnu pojavu. Drugim riječi-

Drugi je primjer žaljenje Ane Karenjine koje analiziram u sljedećoj sekciji. 
ma, predlažem da standardni horori s čudovištima, podžanr iz kojega Walton crpi svoj primjer, ovise upravo o ovakvom tipu reakcija za svoje emocionalne efekte. Sročeno još drugačije, predlažem da opis koji slijedi ima više prednosti spram alternativa: izbjegava problem MPF-a, fenomenološki je uvjerljiviji opis objekta straha, objašnjava više tipova straha i objašnjava strukturu značajnog broja horora o čudovištima. Štoviše, na kraju ovog odjeljka analitički ću argumentirati da fikcijski entiteti ne mogu biti objekt (kvazi-)straha.

Razmotrimo, dakle, iz perspektive objekta emocija dvodijelnu strukturu - prije i nakon punog otkrivenja čudovišta - i tri generalna načina na koji se strah može generirati - napetost, iznenađenje i izgled - u podžanru filmskih horora s čudovištima. ${ }^{4}$

Strukturni pivot oko kojega se većina horora s čudovištima vrti obično je ono što Carroll (1990) naziva pojava (onset) čudovišta ili, preciznije, zato što njegova pojava može biti samo u tragovima (kao kada vidimo samo znakove čudovišta, a ne ono samo), puno otkrivenje čudovišta. Prvi dio počiva na gradnji napetosti i iščekivanja u pripremi za puno otkrivenje tako što se znakovi čudovišta prikazuju tu i tamo. Ovo se može učiniti na različite načine - uporaba negativnog prostora (sve ono što nije u fokusu kadra može biti prostor gdje možemo uočiti tragove čudovišta), blokiranje likova (čudovište može biti točno iza protagonista), nedovoljna ekspozicija (može sakriti čudovište), sjene (također), atipični pokreti unutar kadra (koji odskaču od ljudskih pokreta), usko kadriranje (onemogućivanjem vizualnih informacija o protagonistovoj okolini), produljenje duljine trajanja kadra (koje postavlja pitanje zašto kadar još traje), zloslutni zvukovi i glazba, infrazvuk (frekvencije ispod $19 \mathrm{~Hz}$ koje ljudi ne mogu čuti, ali se osjećaju tijelom i stvaraju nelagodu) itd. Ključno je da će se čudovište u konačnici razotkriti u potpunosti. Jednom kada se to dogodi, upravo zato što gledatelji sada znaju kako izgleda i zvuči čudovište kojega su iščekivali sa strahom u drugom djelu filma, kao što to navode mnogi priručnici o tome kako napisati horor film (usp. Blake i Bailey 2014; Bell 2020), na scenu stupaju nove strategije generiranja straha. Gradnja napetosti u ovom trenutku može imati samo ograničeni efekt i zato njeno mjesto preuzimaju strategije koje generiraju strah iznenađenjem i (vizualnim i zvučnim) izgledom.

Da bismo artikulirali ovu dvodijelnu strukturu i tri strategije generiranja straha, razmotrimo kratki film Lights Out (David F. Sandberg, 2013.). ${ }^{5}$ U prvom dijelu filma (prije punog otkrivenja) dominira gradnja napetosti. Isprva, protagonistica pali i gasi svjetla nekoliko puta zato što svaki puta kada je ono ugašeno određena se silueta pojavljuje na kraju hodnika. Protagonistica prestaje s naizmjeničnim paljenjem i gašenjem kada se biće najedanput pojavi odmah ispred nje, no s okrenutim leđima (što je popraćeno zvukom koji izaziva nelagodu). Nakon što se protagonistica povuče u krevet ostavivši noćno svjetlo u hodniku upaljenim, napetost se nastavlja graditi igrom zvukova koji se približavaju, gašenjem svjetla u hodniku, škripanjem vrata sobe i gubljenjem kontakta utičnice noćnog svjetla. Drhteći ona uspijeva vratiti utičnicu u utikač, istovremeno se svjetlo vrati i u hodnik, ona odahne, no sve je to samo da finale ispadne efektnijim - iznenadni krupni plan koji u potpunosti razotkriva čudovište s prstom na prekidaču. Ovo je opet popraćeno zloslutnim zvukovima i svjetlo se gasi.

Moj je prijedlog da se prije punog otkrivenja gledatelj ne boji nekog čudovišta koje je djelomično vidljivo u mraku, nego iracionalne mogućnosti da nešto poput ovoga vreba negdje u stvarnom svijetu. Strah od toga da čudo- 
višta možda uistinu postoje. Da se nešto stravično poput ovoga zbilja može dogoditi. Da bismo se jednog dana sam mogli naći u sličnoj situaciji. Ono što filmovi ovog tipa rade jest da zazivaju iracionalni strah da još uvijek postoje neka mračna mjesta u svijetu koja nismo potpuno istražili. Logički govoreći, nije nemoguće da čudovište poput ovog, jedno koje je vidljivo samo u mraku, postoji. Možda jednostavno do sada nismo naišli na njega.

Jednom kada se čudovište iz Lights Out potpuno otkrije i na scenu dominantno stupe preostale dvije strategije generiranja straha, opet se radi o tome da je bolje shvatiti strukture stvarnog života, a ne fikcijsko čudovište kao objekt straha. Kao prvo, samo otkrivenje straši upravo zato što ovisi o iznenadnoj pojavi onoga što se zove jump scare, a ne o prirodi fikcijskog bića. Čujemo glasan zvuk, nešto iskoči na ekranu. Kao što niz horora pokazuje, subjekt ove iznenadne pojave ne mora biti zastrašujući sam po sebi. Dovoljno je da je pojava neočekivana. Ova kvaliteta šoka svojstvo je načina predodžbe, a ne onoga što je predočavano.

Dakako da je u ovom specifičnom slučaju u pitanju puno otkrivenje čudovišta. Kadar nam dopušta par trenutaka da doživimo izgled bića u cjelini, figuru nalik ženi s potpuno bijelim očima tamo gdje bi rožnica i šarenica trebale biti, široko razjapljenih usta punih oštrih zubi. No ni ovdje nema razloga da kažemo da je fikcijsko čudovište ono što nas plaši. Možemo jednostavno reći da je ono što straši u prvom redu ono što Walton (1990) naziva rekvizitom u igri maštanja koja konstituira fikciju. Bojimo se izgleda osobe koja je maskirana i našminkana tako da izgleda kao da ima prazne oči i očnjake - rekvizit - a ne zamišljenog čudovišta koje će ubiti svoju žrtvu. U ovom slučaju radi se o neugodnom osjećaju da je nešto gotovo ljudsko, ali ne posve (zasigurno slučaj u suvremenim zombi filmovima). No, rekvizit može biti temeljen i na inherentnim fobijama, poput onih od zmija i paukova ili, u zvučnoj domeni, na vrištanju ili diskordantnim zvukovima.

Povrh zaobilaženja paradoksa fikcije i izbjegavanja MPF-a, koja je prednost opisa objekta emocija kao struktura stvarnog života umjesto fikcijskih entiteta? Kao prvo, ponuđeno objašnjenje bavi se barem trima tipovima straha od u hororima s čudovištima - onoga što slijedi (napetost), jump scares (iznenađenje) i rekvizita (izgled). Naspram toga, Walton (i većina sudionika u debati) bave se samo 'strahom od' u slučaju izgleda. ${ }^{6}$ Nadalje, Walton ne poriče to da jump scaresi djeluju na razini kako je nešto predočeno, a ne na razini što je predočeno. Neporecivo je i da postoje tehnike poput uporabe diskordantnih zvukova ili infrazvuka koji direktno uzrokuju strah (Justin Morrow 2017). Dakle, ako postoji barem jedan tip 'straha od' u hororima o čudovištima čiji su uzrok strukture stvarnog živote, predlažem da je objašnjenje koje počiva isključivo na tim strukturama teoretski jednostavnije i elegantnije od onoga koje bavi fikcijskim entitetima.

4

Drugi je bitan tip straha $\mathrm{u}$ hororima strah $z a$ protagonista. Prethodno sam raspravljao o tome kako se strah za fikcijske likove može artikulirati u raspravi o Tyrionu pa se time više neću baviti.

5

Dostupno na: https://www.youtube.com/ watch? $\mathrm{v}=-\mathrm{fDzdDfviLI}$ (pristupljeno 3. 2 . 2020.).
6

Štoviše, kao što rasprava o Tyrionu pokazuje, moje objašnjenje pokriva i strah za fikcijski lik. 
Objašnjenje 'straha od' onoga što slijedi u terminima iracionalnih hipotetičkih propozicija (gledateljev strah da što ako nešto nalik ovakvom čudovištu uistinu postoji) - na prvi se pogled može učiniti problematičnim. Iako sam i o iracionalnim hipotetičkim propozicijama govorio kao o strukturama stvarnog života, jasno je da su one kao hipotetičke propozicije temeljene na mašti isto kao i fikcijski entiteti. Drugim riječima, zašto bismo se opredijelili za moje rješenje ako oba uključuju maštu? Zato što ponuđeno rješenje fenomenološki bolje opisuje objekt straha od onoga koje zagovara Walton. ${ }^{7}$ Ovo me vodi do druge prednosti predstavljene analize. Ona otkriva da srž horora o čudovištima nije strah od fikcijskih monstruma, nego iracionalna bojazan za sebe. Epitet iracionalan ovdje treba shvatiti u smislu da se suprotno postojećim standardnim dokazima još držimo za logičku mogućnost da čudovišta prikazana u filmu postoje u stvarnom svijetu i da bismo ih mogli susresti. Na kraju krajeva, zašto se ljudi boje ugasiti svjetlo i nakon što je film s čudovištima završio? Kada bi se bojali fikcijskog čudovišta iz filma svjetlo ne bi trebalo moći pomoći. No ako se boje neke strašne mogućnosti u stvarnom životu onda im svjetlo predstavlja priliku da eliminiraju logičku, ali probabilistički malu vjerojatnost da nešto takvo postoji, a ako i postoji da lakše pobjegnu ako se ono uistinu pojavi.

Barem je još jedna prednost ovog rješenja ta da objašnjava strukturu podžanra horora s čudovištima. Kada bismo se bojali čudovišta zbog njegove fikcijske prirode, a ne zbog kvaliteta rekvizita koji ga predstavljaju, onda bi jednom kada se čudovište potpuno razotkrije - kao monstruozna sluz, duh časne sestre, zombi itd. - bilo razumno pretpostaviti da ćemo ga se bojati još više sada kada znamo punu prirodu čudovišta i sve ono za što je sposobno. No ne čini se da je to slučaj. Obično je trenutak otkrivenja istovremeno i klimaks i antiklimaks upravo zbog toga što sada znamo od čega smo netom strepili u napetosti. Jednom kada se nakon punog otkrivenja fokus prebaci s čudovišta na protagonista i kada se priprema ono što Carroll naziva konfrontacijom, za vrijeme tog perioda čudovišta se u pravilu ne bojimo jer fokus nije na njemu. No ako i dalje trebamo zamišljati čudovište na slobodi, imajući na umu njegovu prirodu, trebali bismo ga se i dalje bojati čak i ako film trenutno nije fokusiran ni na njega ni na njegove znakove. Kada bi priroda čudovišta bila ta koja nas straši, samo zamišljanje čudovišta i to što se pokazalo prijetećim trebalo bi nas držati u stanju straha. No kada čudovište nije na ekranu, tj. kada se ne primjenjuju strategije za generiranje straha, samo zamišljanje čudovišta nije dovoljno da nas preplaši. Ovo pokazuje da nije fikcijski entitet taj kojega se bojimo, nego strukture stvarnoga života koje su evocirane već spomenutim strategijama. To je ujedno i razlog zašto nas odvraćanje pogleda s ekrana ili zatvaranje očiju za vrijeme projekcije trenutačno lišava straha ${ }^{8}$ Ovdje vrijedi zastati na trenutak i artikulirati ovaj argument detaljnije, uz pomoć Carrollove definicije art-horora. U njegovoj teoriji osjećamo emociju art-horora spram čudovišta ako i samo ako smo u stanju agitiranosti koje je uzrokovala misao da je čudovište moguće i da istovremeno predstavlja prijetnju i da je nečisto (Carroll 1990: 27). Imajući na umu da je za Carrolla emocija art-horora različita od straha i da za prvu nečistoća igra ključnu ulogu, možemo staviti u zagradu koncepte art-horora i nečistoće. Ovo nam omogućuje da parafraziramo Carrolla i kažemo da se bojimo fikcijskih čudovišta ako i samo ako je naše stanje agitacije uzrokovano mišlju da je čudovište moguće i da predstavlja prijetnju. Poanta je da nakon punog otkrivenja mi i dalje zamišljamo (mašta je ovdje shvaćena kao oblik misli) mogućnost postojanja i prijeteću prirodu čudovišta, no to u nama ne uzrokuje strah. To znači da nas ne plaši fikcijsko 
čudovište već strategije generiranja straha pri čemu se napetost, iznenađenje i izgled svode na strukture stvarnog života.

Sročeno formalnije:

1) fikcijsko čudovište u hororu specifičan je sadržaj mašte; ${ }^{9}$

2) fikcijsko čudovište u hororu kvazi-straši (Walton 1978) ili straši (Carroll 1990);

3) iz 1) i 2) slijedi da je specifični sadržaj mašte ono što kvazi-straši ili straši;

4) no, specifični sadržaj mašte niti kvazi-straši, niti straši sam po sebi;

5) iz 3) i 4) slijedi da u hororu fikcijsko čudovište niti kvazi-straši, niti straši;

6) ipak, horor kvazi-straši ili straši;

7) ili fikcijsko čudovište kvazi-straši ili straši ili straše strukture stvarnog života (napetost, iznenađenje i izgled);

8) iz 5), 6) i 7) slijedi da u hororu straše strukture stvarnog života.

\section{Generalizacije}

Mogu li se prethodne tvrdnje poopćiti van horora i povrh emocije straha?

Drugi primjer ovog tipa koji se u diskusijama redovito navodi je Ana Karenjina. Makar većina danas smatra da žalimo fikcijsku Anu, u prošlosti su kružili argumenti da zapravo imamo osjećaje spram struktura stvarnog života. Paskins (1977) i Charlton $(1984,1986)$ predložili su da imamo osjećaje spram ljudi koji su ili bi mogli biti poput Ane. Weston (1975) i McCormick (1988) predložili su varijantu ove teze po kojoj se osjećaji odnose na općenite životne istine koje djelo prenosi. Kako su ovi argumenti predloženi kao generalna rješenja paradoksa fikcije, samo je jedan protuprimjer dovoljan da ih se ospori (usp. Yanal 1999). I uistinu, simpatiziranje Tonyja Soprana potkopava Paskinsonovu i Charltonovu tezu zato što, kada bi netko poput Tonyja Soprana postojao u stvarnom životu, ne bismo ga simpatizirali. Stvar je u tome da su emocije spram fikcijskog Tonyja i hipotetskog Tonyja u stvarnom životu suprotne - simpatija naspram prezira. Simpatiziranje fikcijskog Tonyja predstavlja problem i za Westona i McCormicka zato što simpatija ne može biti posljedica neke generalne životne istine koju Obitelj Soprano prenosi, štogod ona jest. Štoviše, analiza straha u ovom članku također predstavlja protuprimjer ovakvim formulacijama. Strah od iznenadnih šokova i izgleda rekvizita ne tiče se ni ljudi koji su ili koji bi mogli biti kao sluzavo čudovište, ni generalnih životnih istina. Moj strah za Tyriona, pak, opet je o nečemu drugom: o očekivanjima i ulogu osobnog vremena.

Dakako, ono bolje opisuje moje iskustvo objekta emocije i u prvom redu uspjeh ovog djela argumenta ovisi o tome koliko se slaže $\mathrm{s}$ čitateljevim iskustvom objekta emocija pri gledanju horora. No u nastavku slijedi formalni argument zašto fikcijski entiteti nisu koherentan objekt emocija.

8

Vjerujem da ovo objašnjava i zašto je horor jedan od najtežih žanrova u smislu proizvodnje željenog efekta. Toliko toga počiva na otkrivenju čudovišta, no jednom kada se ono potpuno otkrije teško je držati publiku u strahu.

Specifičnije, sadržaj autorizirane mašte sa svojstvima koje su za Carrolla mogućnost postojanja i prijetnja. 
Premda se gornje tvrdnje ne mogu generalizirati na sve fikcijske emocije, to ne znači da su iste pogrešne kada se radi o primjerima poput Ane Karenjine. Radfordovo inzistiranje na tome da žalimo $n j u$, a ne nekoga drugog (tko god to bio) poput nje ne predstavlja problem zato što se, kao što to Paskins objašnjava, žaliti $A n u$ svodi upravo na žaliti nekoga (tko bi mogao biti) poput nje. Istovremeno, trebamo biti oprezni s nešto drugačijim primjerima. Već sam spomenuo mržnju prema Skyler White i zaluđenost Edwardom Cullenom. Ovu emociju spram Cullena bolje je shvatiti kao opsesiju o, ma koliko nerealnoj, mogućnosti da bi netko toliko privlačan i nježan, a istovremeno uzbudljiv i opasan mogao ući u naš tinejdžerski život. No ovdje se ne radi ni o općenitoj životnoj istini ni o osobi nalik Edwardu. ${ }^{10}$ Za razliku od horora, gdje se svi gledatelji trebaju bojati čudovišta, ovdje svi gledatelji trebaju samo simpatizirati Edwarda, a ne biti zaluđeni njime. Zaluđenost je reakcija koja je relativno uobičajena samo za jednu podskupinu gledatelja - tinejdžerke (Parke i Wilson 2014).

Mržnja prema Skyler White i njene donekle pretjerane kontrole nad svojim mužem u seriji do te razine da glumica Anna Gunn koja je utjelovljuje prima prijetnje smrću zapravo je točnije shvatiti kao preziranje takvog bilo potencijalnog bilo stvarnog ponašanja (vlastitog) ženskog partnera i onih koji ga utjelovljuju - ukratko, ženomrstvo. Ovo opet ne potpada pod gornja objašnjenja zato što ova reakcija ne predstavlja (potpuno) namjeravanu emocionalnu reakciju. Drugim riječima, ni rješenja u ovoj sekciji ni iz prvoga dijela članka nemaju puno toga za reći o reakcijama koje nisu generalno ili uopće planirana, ali koja konstituiraju relativno tipične reakcije za određene podskupine gledatelja (tinejdžerke i ženomrsce).

\section{Zaključak}

Usprkos svemu rečenome, u konačnici ipak ostaje činjenica da je teško poreći (1). Simpatija ili antipatija spram fikcijskih likova emocije su koje je teško reartikulirati u terminima struktura stvarnog života. Drugim riječima, povrh pošalica koje se mogu uživati na ravni koja nije fikcijska, kao što to demonstrira izdanje knjige The Wit \& Wisdom of Tyrion Lannister, mislim da je ispravno kazati da sam autentično gajio pozitivne emocionalne dispozicije - simpatiju - spram Tyriona kao fikcijskog lika, tj. kao strukture zamišljanja ili sadržaja mašte. Iako se nisam uistinu bojao za Tyriona ili brinuo da bi on mogao umrijeti, smatram da je korektno kazati da mi se Tyrion sviđa. Iako sam ponudio precizniji fenomenološki opis Charlesovih emocija i nekih drugih klasičnih primjera, čini se da je paradoks fikcije još uvijek na snazi drugdje.

No to ne znači da nismo postigli nikakav napredak po pitanju paradoksa fikcije. Postoji nešto zajedničko emocijama čije smo objekte identificirali kao strukture stvarnog života naspram onih čiji objekti ostaju fikcijski entiteti postojanje jasnih akcija ili bihevioralnih reakcija koje vežemo uz njih. Dok u kontekstu stvarnog života emocije redovito imaju objekte (usp. Friend 2010), samo neke emocije imaju tipične akcije. ${ }^{11}$ Strah, na primjer, povlači bijeg (od objekta) ili borbu (s objektom). Žaliti nekoga redovito rezultira u pomaganju istog. Agresivno ponašanje prema objektu standardan je odgovor na mržnju. Tipična akcija povezana sa zaluđenošću pokušaji su bivanja u blizini objekta emocije. Naspram ovih emocija, simpatija i antipatija, nemaju jasno povezane akcije. Ove emocije znače imati generalno pozitivan ili negativan stav spram objekta u pitanju, no ne specificiraju jasnu akciju koja proizlazi iz njih. Mo- 
žemo potapšati osobu koju simpatiziramo po ramenu ili se namrštiti kada vidimo osobu koja nam je antipatična, ali ovo nisu jasno definirani tipovi akcija poput prijašnjih. Štoviše, u slučajevima simpatije i antipatije, izostanak bilo kakve akcije također je potpuno tipičan odgovor.

Možemo kazati, dakle, da emocije koje generiraju strukture stvarnog života, naspram onih koje induciraju fikcijski entiteti, imaju snažan i jasan akcijski potencijal u toj mjeri što sa sobom imaju jasno asociranu bihevioralnu reakciju. Ovo je u skladu s jednim od glavnih značajki fikcijskih entiteta - njihove standardne disocijacije od bihevioralnih efekata. Ako fikcijski entiteti u pravilu nemaju bihevioralne efekte, tada bi bilo razumno da fikcijski entiteti generiraju samo one emocije koje nemaju jasno asocirane akcije. Obrnuto, također bi imalo smisla da fikcijski entiteti ne generiraju emocije koje imaju jasno asocirane akcije. Nadalje, samo bi strukture stvarnog života morale moći generirati emocije koje imaju jasne bihevioralne reakcije. ${ }^{12}$ I uistinu, upravo se po ovim linijama dijele emocije koje smo ovdje raspravljali.

Ono što preostaje, status je MPF-a. Emocije koje generiraju strukture stvarnog života identificirane ovdje - strah, zaluđenost, mržnja, sažaljenje - ujedno su i višeg intenziteta od onih koje povezujemo s fikcijskim entitetima simpatija i antipatija. Ovo izgleda obećavajuće za MPF jer to koliko marimo ključ je problema. Istovremeno, moglo bi se kazati i to da i simpatija i antipatija uzrokuju MPF ako su emocije koje imamo spram stvarnih ljudi manjeg intenziteta ili nepostojeće. Moguće je da više simpatiziramo Tyriona nego, recimo, lokalnog mladića u problemima. U ovom slučaju mogli bismo kazati da ovo zapravo nije primjer MPF-a, već patološko pitanje u smislu da bi naša normalna emocionalna reakcija spram stvarnih ljudi trebala biti intenzivnija. MPF bi tada bio zapravo o tome da čak i kada normalno emocionalno reagiramo na strukture stvarnog života, još je uvijek činjenica da je normalna emocionalna reakcija na fikciju intenzivnija i to je ono što se čini skandaloznim. Koje god rješenje pronašli, nadam se da je ovaj članak pokazao da je MPF problem koji zaslužuje pozornost i koji nam pomaže da promislimo paradoks fikcije iznova.

\section{Literatura}

Bell, Neal (2020), How to Write a Horror Movie, Abingdon - Routledge, Oxon - New York.

Blake, Marc; Bailey, Sara (2013), Writing the Horror Movie, A\&C Black, London.

Carroll, Noël (1990), The Philosophy of Horror: Or, Paradoxes of the Heart, Routledge, New York.

10

Za Yanala, ovo je zato što u stvarnom životu nitko nije vampir. U okvirima iracionalnih hipotetskih struktura predloženih ovdje to što nemaju svi fikcijski likovi odgovarajuće pandane u stvarnom životu nije problem.

11

Zahvaljujem Anni Abraham za ovaj uvid.

12

To što jasno asocirana akcija postoji ne znači da se ona mora provesti, samo da postoji potencijal za istu. Iz ove perspektive posjećivanje umjesto bježanje od horor projekcija nije ništa misterioznije od odlazaka na vožnje vlakovima smrti umjesto izbjegavanja istih - oboje predstavljaju strukture stvarnog života koje generiraju strah. 
Charlton, William (1984), »Feeling for the Fictitious«, The British Journal of Aesthetics 24 (1984) 3, str. 206-216, doi: https://doi.org/10.1093/bjaesthetics/24.3.206.

Charlton, William (1986), »Radford and Allen on Being Moved by Fiction: A Rejoinder«, The British Journal of Aesthetics 26 (1986) 4, str. 391-394, doi: https://doi. org/10.1093/bjaesthetics/26.4.391.

Coleridge, Samuel Taylor (1817), Biographiae Litteraria or Biographical Sketches of My Literary Life and Opinions, Rest Fenner, London.

Eaton, Anne Wescott (2015), »Literature and Morality«, u: Carroll, Noël; Gibson, John (ur.), The Routledge Companion to Philosophy of Literature, Routledge, str. 433-450.

Friend, Stacie (2016), »Fiction and Emotion«, u: Kind, Amy (ur.), The Routledge Handbook of Philosophy of Imagination, London - New York, str. 217-229.

Konrad, Eva-Maria; Petraschka, Thomas; Werner, Christiana (2018), »The Paradox of Fiction - A Brief Introduction into Recent Developments, Open Questions, and Current Areas of Research, including a Comprehensive Bibliography from 1975 to 2018 «, Journal of Literary Theory 12 (2018) 2, str. 193-203, doi: https://doi.org/10.1515/jlt-2018-0011.

Kroon, Fred; Voltolini, Alberto (2019), »Fiction«, u: Zalta, Eward N. (ur.), The Stanford Encyclopedia of Philosophy. Dostupno na: https://plato.stanford.edu/archives/win2019/ entries/fiction/ (pristupljeno 3. 2. 2020.).

Hume, David (1757), »Of the standard of taste«, u: Hume, David, Essays: Moral, Political and Literary (1875), Longmans, Green, and Co., London.

Liao, Shen-yi; Gendler, Tamar (2019), »Imagination«, u: Zalta, Edward N. (ed.), The Stanford Encyclopedia of Philosophy. Dostupno na: https://plato.stanford.edu/archives/ win2019/entries/imagination/ (pristupljeno 3. 2. 2020.).

McCormick, Peter J. (1988), Fictions, Philosophies, and the Problems of Poetics, Cornell University Press, Ithaca.

Morrow, Justin (2017), »The Science of Silence: Disquieting Uses of Infrasound in Movies«, No Film School (21. 6. 2017.). Dostupno na: https://nofilmschool.com/2017/06/ disquieting-uses-infrasound (pristupljeno 3. 2. 2020.)

Parke, Maggie; Wilson, Natalie (ur., 2014), Theorizing Twilight: Critical Essays on What's at Stake in a Post-Vampire World, McFarland, Jefferson.

Paskins, Barrie (1977), »On Being Moved by Anna Karenina and Anna Karenina«, Philosophy 52 (1977) 201, str. 344-347, doi: https://doi.org/10.1017/s0031819100027182.

Radford, Colin; Weston, Michael (1975), »How Can We Be Moved by the Fate of Anna Karenina? «, Proceedings of the Aristotelian Society. Supplementary Volumes 49 (1975) 1, str. 67-94, doi: https://doi.org/10.1093/aristoteliansupp/49.1.67.

Slugan, Mario (2019), Noël Carroll and Film: A Philosophy of Art and Popular Culture, Bloomsbury Publishing, London.

Smith, Murray (2011), »Just What Is It That Makes Tony Soprano Such an Appealing, Attractive Murderer?«, u: Jones, Ward; Vice, Samantha (ur.), Ethics at the Cinema, Oxford University Press, Oxford, str. 66-90, doi: https://doi.org/10.1093/ acprof:oso/9780195320398.003.0003

Stecker, Robert (2011), »Should We Still Care about the Paradox of Fiction? «, The British Journal of Aesthetics 51 (2011) 3, str. 295-308, doi: https://doi.org/10.1093/aesthj/ayr019.

Suits, David B. (2006), »Really believing in fiction«, Pacific Philosophical Quarterly 87 (2006) 3, str. 369-386, doi: https://doi.org/10.1111/j.1468-0114.2006.00267.x.

Vaage, Margrethe Bruun (2015), The Antihero in American Television, Routledge, New York.

Walton, Kendall L. (1978), »Fearing Fictions«, The Journal of Philosophy 75 (1978) 1, str. 5-27, doi: https://doi.org/10.2307/2025831.

Walton, Kendall L. (1990), Mimesis as Make-Believe: On the Foundations of Representational Arts, Harvard University Press. 
Weatherson, Brian (2004), »Morality, Fiction, and Possibility«, Philosophers' Imprint 4 (2004) 3, str. 1-27.

Yanal, Robert J. (1999), Paradoxes of Emotion and Fiction, Penn State Press, Pennsylvania.

\title{
Mario Slugan
}

\section{Fictional Emotions and the Moral}

\section{Dimension of the Paradox of Fiction in Cinema}

\begin{abstract}
The paper offers a twofold intervention in the debates about the paradox of fiction. First, it argues that too much emphasis has been placed on the paradox'epistemological aspect. This has led to a neglect of its ethical dimension. Specifically, little has been said about the ethical issues of regularly caring for fictional entities while exhibiting comparatively far less concern for real-life fellow men and women. Second, the essay argues that it is often the case that it is real-life structures rather than fictional entities that cause emotions. In the case of horror, for example, we are not afraid of the fictional monster but of an off possibility that something like this might exist in the real world. Importantly, the proposal differs from the counterfactualist approaches because it allows that fictional entities may cause emotions. Specifically, emotions which do not have clearly defined accompanying typical actions, such as sympathy and antipathy.
\end{abstract}

\section{Keywords}

paradox of fiction, emotion, morality, film 